\title{
MODERN INTERNATIONAL APPROACHES TO INVESTMENT POLICY OBJECTIVES STATEMENT AND EFFECTIVENESS MEASUREMENT
}

\author{
National Aviation University \\ Kosmonavta Komarova avenue 1, 03680, Kyiv, Ukraine \\ E-mail: cet_nau@bigmir.net
}

\begin{abstract}
The article deals with the macroeconomic consequences of international requirements implementation in the sphere of investment policy objectives statement and efficiency measurement.

Keywords: antimonopoly state policy, international economic organization, investment, investment policy, macroeconomic indicators.
\end{abstract}

\section{Introduction}

The problem of maximizing value added from private and state investment is of great importance for each country in the world. National governments introduce their own guidelines for the definition of investment impact objectives, but there are some comprehensive principles of international approaches to the investment policy objectives statement and indicators of policy effectiveness measurement.

\section{Review of research results}

There is a lot of theoretical and practical research works on the problems of investment increase and foreign investment attracting. The prominent scientists have made the contribution to the fundamental analysis of that problem, including A. Ochrimenko (2012), A. Opaitz (2012), G. Tumpel-Gugeroll (2002), P. Mooslender (2002).

The task of attracting the foreign capitals has ever been the main goal of investment approaches, but the disclosure of proper logics and time trends in the forms of investment changes, in the structure and subjective basis of investment, in the proportion between foreign and domestic capitals as the sources of investment is still not examined enough.

The purpose of the article is to deliver the common fundamental approaches that are carried on abroad and regulate the conditions of getting foreign capital inflows by the particular country. The article contains an attempt to disclose the acceptable indicators for the definition of investment objectives and means of its effectiveness measurement that exist in approaches and requirements to the investment policy in $\mathrm{EU}$ and in the world.

\section{Investment Policy Guidelines}

The comprehensive analysis of foreign investment policy principles contains the list of investment policy guidelines:

- investment and sustainable economic development strategy;

- investment regulation and promotion;

- investment-related policy areas;

- investment policy effectiveness;

Generally it concerns such items as:

a) integrating investment policy in sustainable development strategy of the proper country;

b) maximizing the contribution of investment to the economic value added and to the world competitiveness;

c) establishment, arrangements and procedures of investment-specific policies designing;

d) treatment and protection of investments and investors responsibility;

e) investment promotion and facilitation;

f) coherence of investment policy aims with trade policy, fiscal policy, intellectual property, competition and state aid policies, labour market regulation, access to land, corporate responsibility and governance Code, environment protection, infrastructure and public-private partnerships;

g) arrangement of effective public institutions to implement investment policy;

h) measurement indicators of investment policy effectiveness.

The system of best world practices in investment for development sake also may be adopted or examined for some special use by any other country of the world, e.g. how to improve roads and transport infrastructure (experience of Australia and Peru); how to improve ports (Nigeria), how to improve electricity infrastructure (Chile and New Zealand); how to attract and benefit from foreign 
investment in mining (Canada and Chile); how to integrate foreign investment and skill development (Canada and Singapore) and how to prevent and manage investor-state disputes (Peru).

Speaking about the strategic investment policy priorities we must point that investment policy should be directed towards the realization of national sustainable development goals and strategic development priorities, such as investment in specific forward economic activities; enforcement of public and private mutual investment, especially in the form of partnerships; investment as a contribution to the work opportunities settlement, to the qualitatively improving of productive capacities and to the international competitiveness maintenance.

Investment strategy of such country as Ukraine must be disclosed in its sustainable development strategy and provide transparent signals to the foreign and domestic investors and stakeholders involved in policymaking process.

One of the criteria for determining investment priorities in Ukraine like in other countries must be the skills transfer and job creation in order to prioritize the human resource development policy and its requirements

The transfer of high technologies and the dissemination of know-how should be promoted as one of the criteria for investment priorities determination and be maintained properly by taxation and intellectual property legislations.

The infrastructure development policy should be a part of internal investment policy as far as it satisfies the productive capacities with necessary utilities, roads, seaports, airports or innovative industrial parks.

National investment strategy actually must provide the proper degree of openness to serve the items of entry, establishment and operations of foreign investors with the country's investment policy or with the special law on foreign investment in the national legislation. But general policy of openness and avoidance of investment protectionism must take into account the existing country-specific development needs such as provision of public goods, control over strategic industries and critical infrastructure. Entry or ownership restrictions or limitations of foreign investment in accordance with the country's national right to regulate should be justified by legitimate national development policy objectives and should not be influenced by special interests.
They must be best limited to some stated aims, e.g.:

a) protecting the national interest, national security and control over natural resources, critical infrastructure, public health, the environment;

b) promoting national development objectives in accordance with the national investment strategy.

Such restrictions on ownership or on entry of foreign investment must be in conformity with international commitments and should be clearly specified. The practice of restriction on foreign ownership should be periodically reviewed and screened.

Foreign investors usually are much interested to register ownership or titles to land and other forms of property in order to facilitate access to debt finance that may sometimes lead to the provocative dealings. Foreign ownership over agricultural land is much important in most countries with large rural population or with food security problems. Governments in any case should pay particular attention to the protection of long-term national interests. Adherence to the UNCTAD, FAO, IFAD and World Bank Principles for Responsible Agricultural Investment should be encouraged in Ukraine. By the way, the development of industrial technology or services parks as public-private partnerships can be an example of effective tool to facilitate access to fully-serviced land by domestic and foreign investors.

The widely-spread "freedom of investment operations" term means that governments respect the freedom of operations of private companies, including the freedom of investors to decide whether they want to invest at home or abroad. At the same time, the countries have the right and the duty to regulate the treatment in order to provide stability and predictability of the investment climate in the proper country. When development objectives require policies that distinguish between foreign and domestic investment, they need to be in line with international commitments, such as REIOs.

One of the main points of concern of foreign investors is the country's treatment and protection of investors, especially the problem of funds transfer. This problem is tightly connected with the national rules about capital account transactions and the potential restrictions due to the balance of payment crises. When macroeconomic considerations warrant restrictions on the transfer of capital, countries should seek to treat foreign investment-related transactions differently from other capital account transactions. 
Countries should guarantee the freedom to transfer and repatriate capital related to investments in productive assets. According to the international approaches, countries should also guarantee the free convertibility of their currency for current account transactions, including earnings and dividends, interests, royalties and others. Any restriction to convertibility for current account transactions should be in accordance with existing international obligations and flexibilities, in particular with the IMF Articles of Agreement.

Usually, states should honour their obligations deriving from investment contracts with investors, unless they can invoke significant changes of circumstances and legitimate reasons in accordance with national and international laws.

Expropriations or nationalization may take place being caused by legitimate public policy aims, but foreign investors insist that expropriations should be undertaken in a non-discriminatory manner and conform to the due process of law and compensations should be provided. Decisions should be opened to recourse and reviews in order to avoid arbitrariness.

In this case governments should assign the responsibility and accountability for the implementation of measures to provide effective compliance with commitments under IIAS. Special alternative dispute resolution mechanisms are regarded to be the effective means to avoid international arbitration of disputes. Governments should also encourage adherence to international standards of responsible investment and Codes of conduct by foreign investors. Standards which serve as reference include:

- the ILO Tri-partite Declaration (ILO International Labour Organization);

- the OECD Guidelines for Multinational Enterprises;

- the UNCTAD Principles;

- FAO, IFAD and World Bank Principles for Responsible Agricultural investment;

- the United Nations Guiding Principles on Business and Human Rights.

All these international documents as well as national legislation according investment and governmental investment policy proclaim the idea that investors' first and foremost obligation is to comply with a host country's laws and regulations and the country treats indiscriminately the national and foreign investors in accordance with national legislation, the last being referred and correlated with International codes and principles.
On the way of investment facilitation the responsibility and accountability should be realized and assigned to a special investment promotion agency to assist investors in complying with administrative and procedural requirements. The mission, structure and objectives of the investment promotion agency should be based on the national investment policy objectives of the host country and might include image building, targeting, facilitation, aftercare and advocacy. It connects the Government and investors and supports the efforts to improve general business climate, to resolve cross-ministerial issues through its communication channels and by reposting to the Government.

The operational board of such agency may include usually the members from relevant ministries and committees as well as from the private sector. Their mission will be not only to promote the investment policy objectives, but to introduce the best international investment regulation practices. The investment promotion agency works closely with regulatory agencies dealing directly with investors. It should promote a client-oriented attitude in public administration and may enlist the diplomatic service to strengthen promotion efforts. The granting and administration of incentives should be the responsibility of an independent entity or ministry that does not have conflicting objectives or performance targets for investment attraction. And as a conclusion, we must add that environmental, labour or wage standards as well as other social standards should not be lowered or postponed on the way to attract investment or to compete for investment capital from abroad.

The list of measures that Government should consider to promote business linkages include:

a) direct intermediation between national and foreign investors to close information gaps;

b) financial or another support to national companies for technology upgrading;

c) selective foreign direct investment targeting;

d) establishment of national norms and standards coherent with international standards (e.g. ISO quality standards);

e) incentives for foreign investors in promotion of entrepreneurship.

Investment policy can be best realized due to the collaboration of the proper country with the world organizations, such as IMF, World Bank, WTO, ILO and others. Access to global markets is important for resource-and efficiency-seeking foreign investors, and the size of local or regional markets is a point of 
concern for market-seeking investors. That's why participation of a proper country in international trade agreements and integration at the regional level should be considered an integral part of sustainable development strategy and a key factor in promoting investment.

Investment policy is much connected with the wide scope of investment-related policies. As it was already mentioned, the coherent policies are: trade policy, tax policy, monetary and credit policies, competition policy, state aid policy, environmental policy, intellectual property and labour regulations, corporate responsibility and antimonopolistic policy.

Sometimes one could hardly estimate what policy plays more active role in encouraging investment, and by what means and instruments, by what forms and in what directions properly it is done. It is a macroeconomic problem that the investment policy mustn't exist separately from anticyclic economic policy. Regulation of total entrepreneurial activity must stand beside the investment policy, just similar to the policy of economic growth that must accompany the policy of sustainable development. And at last, the macroeconomic policy of the state must take into consideration the current conditions of special phase of economic cycle (whether it is a crisis or a boom, or a prolonged depression) when establishing its investment policy objectives for the short-run or the long-run time period. The goals of investment, as being the economic priorities, may be put and achieved effectively only when the internal and external lags of each policy would be taken into consideration. So, the problem of time-coincidence of proper policy instruments and total development objectives (including investment policy objectives) is of great importance. Policy objectives must coincide with policy means and with cycle circumstances in time. That's why the investment policy must have "the objectives tree" and must be structurized not only in terms of branches, financing, means, foreign or domestic investment priorities, direct or indirect forms of investment, but it must have the adequate "time terms" in the ranging of aims according to the current circumstances.

\section{International Approaches to the Investment-related Policies}

Speaking about the international approaches to the investment-related policies we must emphasize, that trade policy of the country (including tariffs and non-tariff barriers, export facilitation finance, import insurance schemes, support to the compliance with international norms and standards) can influence on investment in specific industries, promoting or discouraging the total industrial development objectives. Efficient border procedures should avoid forming the obstacles to the attraction of exportoriented investment or investment that relies on imports of intermediate goods and therefore should influence on the national structure of economy.

Fiscal policy of the state, especially the corporate taxation and fiscal incentives for effectiveness should be an integral part of investment policy. The structure of the tax regime should touch administrative and compliance costs for investors, monitoring, costs for the tax authorities and forgone revenues linked to tax evasion or tax engineering.

The avoidance of undue complexity of income tax law is very essential for all investors. The common international approach in the tax policy demands neutrality in its treatment of domestic and foreign investors. Fiscal incentives can be used for the encouragement of investment in some specific industries or in order to achieve some specific objectives (regional development, jobs creation, skills upgrading, technology allocation and struggle against poverty), but not to serve as a compensation for an inappropriate general tax regime. The world experience resumes that exceptions from general corporate income tax regime in the form of tax incentive quickly lead to distortions, to the unintended tax avoidance opportunities, become difficult to monitor, create administrative costs and project special interests at the expense of the whole society.

The best practice of transfer pricing rules gives the examples how to minimize tax evasion. International cooperation between tax authorities of different countries permits to fight the bad manipulative transfer pricing practices of the big companies.

Double taxation treaties permit the principle of "taxation at the source" to prevail and to promote inward and outward investment. And a country's international tax treaty network should focus on the types of investment prioritized in its investment policy.

Intellectual property is also being an investmentrelated problem. Countries like Ukraine must integrate the flexibilities in intellectual property protection granted under international treaties (e.g. WTO, TRIPS agreement) into national legislation and create the opportunities to attract investment (e.g. IT-sphere, production of pharmaceuticals etc.) 
Investment policy makers in Ukraine like in other countries should cooperate with competition and antimonopoly authorities to prevent anti-competitive practices, especially in the regulated sectors (public transport, telecommunications and utilities).

Competition laws and privatization policy like abroad should support the investment policy objectives by avoiding market exclusivity and preventing abuse of dominating at the market.

Analysing the strategic decisions concerning special sectors to be opened to private investment, especially foreign investment, Governments should craft a legal framework for concession contracts and public-private partnerships. The long-term concession agreements in infrastructure should provide assurances to investors and property rights.

But concessioning to private investors should aim to install competition and not to replace a public monopoly with a private one. The introduction of private concession in the traditional spheres of natural monopolies should be limited to the cases where it increases efficiency and the volume of services delivered.

National governments in their investment approaches usually encourage the compliance with world standards of responsible investment and corporate behavior that include:

a) technical assistance to local industry in order to improve their ability to work with investors that prefer certified products;

b) incorporating the standards into regulatory initiatives;

c) turning voluntary standards into hard law regulation.

Countries should aim to adopt international standards of corporate governance for large businesses under their Company law or Commercial code in such spheres:

a) protection of minority shareholders;

b) transparency and disclosure on a timely, reliable and relevant basis;

c) external audit of accounts;

d) adoption of high standards and codes of good practices on corruption, health, environment and safety issues.

The OECD Principles of Corporate Governance and the UNCTAD Guidance on Good Practices in Corporate Governance Disclosure may serve as international guidance. Corporate reporting standards should provide the possibility to control structures, finances and operations as well as health, employment and environment impacts.
It is useful to distinguish investment projects based on environmental criteria. Governments should ensure foreign investors that environmental licensing procedures are conducted without undue delay and international standards of environment protection would be implemented and adhered.

The problem of investment policy effectiveness is tightly connected with the entire economic policy design and implementation and might be indicated thereto the sustainable development strategy. But the changing needs and circumstances insist on its reviewing every $3-4$ years concerning the gaining of objectives and returning of the most costly investment policy measures, e.g. incentives. The investment policy effectiveness measurement supposes a set of indicators to estimate benefits or losses in order to find the causes of underperformance and the new ways to perform better. The international common approaches to the investment policy effectiveness measurement assume the following indicators for the attraction of investment estimation:

a) investment inflows (total and by industry);

b) investment flows as a share of gross output (GDP) and capital formation (total and by each industry);

c) greenfield investment as a share of total investment.

\section{Indicators of Investment Effectiveness Measurement}

The indicators for objectives of investment contribution to the economy include:

a) total value added due to the investment activity;

b) value of gross fixed capital formation;

c) total and net exports generation;

d) number of formal business entities supported by the investment;

e) total fiscal revenues resulting from the investment facilitation of economic activity;

f) job creating and employment generated by investment;

g) wages and total household income generated by the investment;

h) typologies and employee skill levels (especially technology levels of jobs);

i) labour impact indicators, concerning employment structure changes and skills upgrading;

j) social impact indicators, concerning number of families lifted out of poverty and expansion of access to the basic goods and services; 
k) environmental indicators, including greenhouse gas emissions and carbon credit revenues, energy and water consumption efficiency and enterprise development in eco-sectors;

1) local development indicators including technology dissemination.

The implementation of international approaches by each country supposing to attract the foreign investment includes the fulfillment of some macroeconomic requirements.

The country must satisfy the special macroindicators with the eligible figures. These indicators are:

a) inflation rates;

b) annual government deficit;

c) government debt;

d) exchange rate mechanism;

e) long-term interest rates.

All these indicators formulate the macroeconomic requirements to the investment climate and business surrounding in the proper country, like Ukraine. The host country that needs foreign capital inflow must provide the competition conditions including the changes in the Company law and price stability as parts of the eligible business environment for companies.

According to the international approaches Ukraine needs a new law on the state aid and a new state aid system with the reglamentation of choice principles for the beneficiaries of state aid that might not coincide with the requirements of investment attraction.

The investment policy must provide the equal treatment to the foreign and domestic investors, while the state aid policy usually supports special tax regimes, government guarantees given to the individual companies or sectors and understandable procedures of giving subsidies to the proper firms.

At the same time the problem of state aid is connected besides with the problems of state budget, export capacities of Ukrainian companies, state sector of the economy and its competitiveness.

However, the elimination or diminishing of state aid to the large industrial enterprises in Ukraine according to the international prescriptions may be compensated by the investment inflows from domestic and foreign private capital to the Ukrainian economy.

\section{Conclusions}

The implementation of international requirements in the sphere of investment policy objectives and introduction of its effectiveness measurement indicators permit to attract and encourage investment that provides a contribution to the economic growth and to the social prosperity. Ukraine has a lack of venture business, credit interest rates, there are some conflicts of interest between domestic and foreign strategic investors, but the main conclusion is that investment process is not associated only with the huge investors or transnational companies, but also with millions of small and medium-size companies, that invest in their own business. Thus, Ukraine should design its investment policy on the wide personal basis of investors using the best foreign practices and in adherence with the modern international approaches to the investment policy and its effectiveness measurement.

\section{References}

Ochrimenko, A. 2012. Investment Policy of Ukraine and International Investment. [Electronic resource]. Available from Internet: <http://eco nomics.unian.net/rus/detail/151186.>

Opaitz, A. 2012. Internation Protection of Investments. The Case of Ukraine. World Finance Review. September, N 3: 3-25.

Tumpel-Gugeroll, G.; Mooslender, P. 2002. Enlarged European Union. Northampton MA, USA. Edward Edgar. 435 p. 
Т.І. Біленко. Сучасні міжнародні підходи до визначення цілей та засобів обрахування ефективності інвестиційної політики

Національний авіаційний університет, проспект Космонавта Комарова, 1, Київ, Україна, 03680

E-mail: cet_nau@bigmir.net

Показано підходи національних урядів до визначення цілей інвестиційної політики. Наведено загальні правила міжнародних підходів до встановлення цілей інвестиційної політики й систему індикаторів обрахування ії ефективності. Розглянуто загальні вимоги до розробки інвестиційної політики, що включають систему відповідних індикаторів обрахунку макроекономічної ефективності національної інвестиційної політики на базі узгоджених міжнародних підходів.

Ключові слова: державна антимонопольна політика, інвестиції, інвестиційна політика, макроекономічні індикатори, міжнародні економічні організації.

Т.И. Биленко. Современные международные подходы к определению целей и средств измерения эффективности инвестиционной политики

Национальный авиационный университет, проспект Космонавта Комарова, 1, Киев, Украина, 03680

E-mail: cet_nau@bigmir.net

Показаны подходы национальных правительств к определению целей инвестиционной политики. Приведены общие правила международных подходов к установлению целей инвестиционной политики и система индикаторов измерения ее эффективности. Рассмотрены общие требования к разработке инвестиционной политики, включающие систему соответствующих индикаторов подсчета макроэкономической эффективности национальной инвестиционной политики на базе согласованных международных подходов.

Ключевые слова: государственная антимонопольная политика, инвестиции, инвестиционная политика, макроэкономические индикаторы, международные экономические организации.

Tetyana Bilenko. Candidate of Economic. Associate Professor.

Head of Economic Theory Department, National Aviation University, Kyiv, Ukraine.

Education: Economic Department of Kyiv State University named after T. Shevchenko, specialty "Political Economy", Ukraine (1979).

Research area: monetary policy, state investment policy, investment activities, international economic organizations, state budget.

Publication: 136 .

E-mail: cet_nau@bigmir.net 